\title{
Tests of Impregnation Speed of Electrotechnical Pressboard with Insulating Oil
}

\section{Kozak}

Lublin University of Technology,

Nadbystrzycka str., 38A, Lublin 20-618, Poland

Received 04.03.2020

Accepted for publication 21.04.2020

\begin{abstract}
The paper presents a new test stand for ivestigating the rate of penetration of transformer oil through electrotechnical pressboard. The stand consists of a pipe, to the lower end of which is glued a pressboard plate. The pipe is filled with insulating oil. A mirror is placed under the plate, which directs its image to the lens of the camera, which takes a series of photographs at a given time interval. After being saturated with the insulating oil, the pressboard changes colour from light to dark yellow. The absorbing time is defined as the time in which a dark yellow spot appears on the lower light surface of the pressboard after the pipe is filled with oil.

A new way of determining capillary diameters has been developed when the number of capillaries is unknown and the volume of liquid flowing through them is not measurable. The distribution of the times of penetration of transformer oil through $2 \mathrm{~mm}$ thick electrotechnical pressboard was determined, the values of which range from about $220 \mathrm{~min}$ to about $550 \mathrm{~min}$. It was found that the radii of capillaries through which the insulating oil penetrates are within the range from about $45 \mathrm{~nm}$ to about $70 \mathrm{~nm}$. Due to the structure of the pressboard, which consists of cellulose fibres, arranged more or less tightly, there are capillaries in the structure of the board, each of which has sections of varying lengths of radii. This means that short sections of a single capillary can have radii both smaller than $45 \mathrm{~nm}$ and larger than $70 \mathrm{~nm}$.

The developed stand and the new analysis method can be used for testing various porous materials for penetration by various liquids.
\end{abstract}

Keywords: electrotechnical pressboard, insulating oil, impregnation, capillary.

DOI: $10.21122 / 2220-9506-2020-11-2-140-147$

\begin{tabular}{ll}
\hline Aдрес для переписки: & Address for correspondence: \\
C. Kozak & C. Kozak \\
Lublin University of Technology, & Lublin University of Technology, \\
Nadbystrzycka str., 38A, Lublin 20-618, Poland & Nadbystrzycka str., 38A, Lublin 20-618, Poland \\
e-mail: c.kozak@pollub.pl & e-mail: c.kozak@pollub.pl \\
\hline Для цитирования: & For citation: \\
C. Kozak. & C. Kozak. \\
Tests of Impregnation Speed of Electrotechnical Pressboard & Tests of Impregnation Speed of Electrotechnical Pressboard \\
with Insulating Оil. & with Insulating Oil. \\
Приборы и методы измерений. & Devices and Methods of Measurements. \\
2020. - Т. 11, № 2. - С. 140-147. & 2020, vol. 11, no. 2, pp. 140-147. \\
DОI: $10.21122 / 2220-9506-2020-11-2-140-147$ & DOI: 10.21122/2220-9506-2020-11-2-140-147
\end{tabular}




\title{
Измерение скорости просачивания трансформаторного масла через электротехнический картон
}

\author{
Ч. Козак \\ Люблинский технологический университет, \\ ул. Надбыстрицкая, 38А, Люблин 20-618, Польша
}

Поступила 04.03.2020

Принята к печати 21.04.2020

В работе представлена новая установка для исследования скорости просачивания трансформаторного масла через электротехнический картон. Установка состоит из прозрачной трубы, к нижнему концу которой приклеена пластинка электротехнического картона. Затем в трубу вливается трансформаторное масло. Под пластинкой находится зеркало, направляющее её изображение в обьектив фотоаппарата, который регистрирует серию изображений пластинки с заданным временным интервалом. Электротехнический картон, смоченный трансформаторным маслом, изменяет свой цвет со светложёлтого на тёмно-жёлтый. Время просачивания трансформаторного масла через электротехнический картон определяется по появлению на изображении поверхности картона тёмно-жёлтого пятнышка, свидетельствующего о просачивании трансформаторного масла через пластинку.

Разработан способ расчёта среднего диаметра капиляров, через которые трансформаторное масло просачивается через электротехнический картон в случае, когда их число является неизвестным, в связи с чем обьём вытекающей через один капиляр жидкости невозможно измерить. Установлено, что в разных местах пластинки картона с толщиной 1 мм времена просачивания различаются. На основании проведённых измерений определено распределение времён просачивания, которые изменяются от 224 мин до 556 мин. Рассчитаны радиусы капиляров, через которые трансформаторное масло просачивается через электротехнический картон. Их величины изменяются от 47 нм до 75 нм. Структура картона представляет собой волокна целюлозы, упакованные достаточно плотно. В связи с этим между волокнами существуют капиляры, каждый из которых состоит из участков с изменяющимися по длине радиусами. Таким образом, в картоне имеются короткие участки капиляров с радиусами как меньшими 47 нм, так и большими 75 нм.

Разработанные установка и способ расчёта размеров капиляров могут быть использованы для исследования протекания различных жидкостей через пористые материалы.

Ключевые слова: электротехнический картон, трансформаторное масло, импрегнация, капиляры.

DOI: $10.21122 / 2220-9506-2020-11-2-140-147$

\begin{tabular}{ll}
\hline Адрес для переписки: & Address for correspondence: \\
C. Kozak & C. Kozak \\
Lublin University of Technology, & Lublin University of Technology, \\
Nadbystrzycka str., 38A, Lublin 20-618, Poland & Nadbystrzycka str., 38A, Lublin 20-618, Poland \\
e-mail: c.kozak@pollub.pl & e-mail: c.kozak@pollub.pl \\
\hline Для цитирования: & For citation: \\
C. Kozak. & C. Kozak. \\
Tests of Impregnation Speed of Electrotechnical Pressboard & Tests of Impregnation Speed of Electrotechnical Pressboard \\
with Insulating Оil. & with Insulating Oil. \\
Приборы и методы измерений. & Devices and Methods of Measurements. \\
2020. - Т. 11, № 2. - С. 140-147. & 2020, vol. 11, no. 2, pp. 140-147. \\
DОI: $10.21122 / 2220-9506-2020-11-2-140-147$ & DOI: 10.21122/2220-9506-2020-11-2-140-147 \\
\hline
\end{tabular}




\section{Introduction}

The most popular type of electrical insulation used in power transformers is the so-called liquidsolid insulation. Among many technical solutions, the most commonly used is the use of cellulose materials in the form of paper and pressboard as solid elements of insulation. Its popularity is mainly due to its good insulation parameters, ease of manufacture and shaping, and low price. Cellulose is a naturally occurring biopolymer derived from wood. It is composed of repeating glucose groups forming monomers, from which fibres are eventually formed. The number of repeated monomers in a single fiber is an important material parameter and is referred to as the degree of polymerisation (DP). The degree of polymerisation for newly made insulating paper takes the values of about 1200 [1]. During many years of operation, the cellulose fibres disintegrate to the level of $200 \mathrm{DP}$ [2], which is considered to be the end of insulation life. As the cellulose depolymerisation progresses, it gradually loses its electrical and mechanical properties, which may result in catastrophic transformer failure. One of the main factors in accelerating the depolymerisation of paper insulation is the presence of water in it. In order to protect the cellulose insulation from the ingress of water molecules, it is impregnated with insulating liquid. Since the beginning of the 20th century, the commonly used insulating liquid is petroleum-derived mineral transformer oil, which is characterised by low viscosity, good ageing strength, excellent insulating parameters and low price [3]. Another task of the insulating oil is to ensure cooling of the insulation and active elements of the transformer [4]. Moreover, due to their fibrous structure, cellulose materials have free spaces between the fibres in the form of capillaries, in which there is a noticeable amount of air, which during the impregnation process is replaced by oil, increasing the dielectric strength of the insulation. The remaining air in cellulose after improper impregnation, due to its low dielectric permittivity $(\varepsilon \approx 1)$, compared to cellulose $(\varepsilon \approx 4.4)$ and applied insulating liquid $(\varepsilon \approx 2.2-3.2)$, causes local electric field intensity which may lead to partial discharges [5]. Important parameters of cellulose materials are their absorbability - the volume of oil which is absorbed by a unit of material volume, and the rate of impregnation - the impregnation time. Such parameters also include capillary dimensions and distribution of their diameters.
Theproperlyperformedimpregnationprocessiscrucial for failure-free transformer operation [6]. In atmospheric conditions, impregnation of the pressboard with transformer oil takes over 46 days [7]. The use of vacuum impregnation, in which the pressboard is treated with oil under reduced pressure, allows to shorten the impregnation time to even several dozen minutes [8]. Previous studies revealed the presence of statistical distribution of capillaries present in the pressboard $[9,10]$.

The aim of the present study is to present the position for testing the rate of transformer oil impregnation through the electrotechnical pressboard and the method of determining the dimensions of capillaries when their number is unknown and the volume of liquid flowing through them is impossible to record.

\section{The oil-impregnation test stand}

In order to test the process of penetration of insulating oil through the pressboard, a measuring stand and the method of optical recording of the time of penetration of oil through the pressboard sample were prepared. The basis of the new method is that after moistening its surface with insulating oil, the pressboard is changing its colour from light to dark yellow (Figure 1).

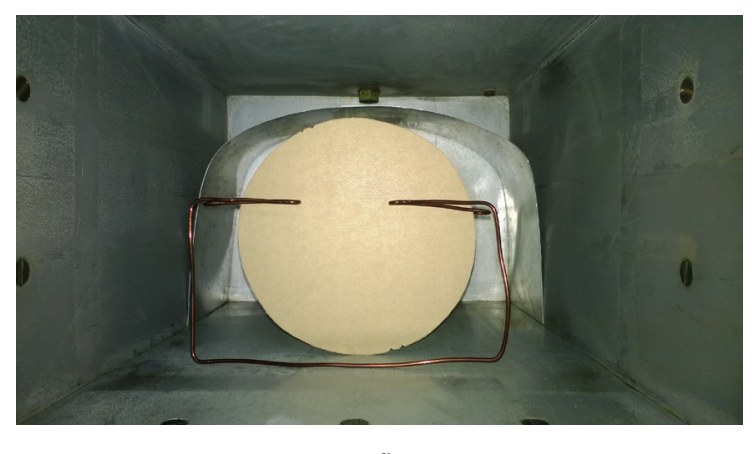

$a$

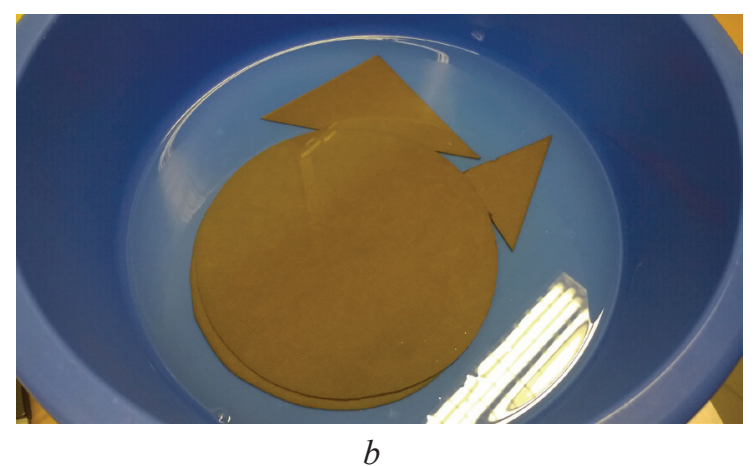

Figure 1 - Dry $(a)$ and transformer oil moistened $(b)$ pressboard samples 
Figure 2 shows a diagram and basic elements of the measuring stand. The main element of the stand is a $2 \mathrm{~m}$ long polycarbonate pipe. A plate made of pressboard is tightly glued to the lower end of the pipe. Under the vertically positioned pipe, a vessel is placed to catch oil in case the pipe and plate should get unsealed. A mirror is placed in the vessel at a $45^{\circ}$ angle, directing the image of the pressboard plate to the camera lens. By using a concave mirror, the sample image was magnified approximately 1.5 times its actual size, which improved the image resolution. After starting the cyclic operation of the camera, the tube is filled with transformer oil so that the height of its column is $(1000 \pm 1) \mathrm{mm}$. In the research, electrotechnical pressboard and transformer oil intended for the production of power transformers were used, obtained from the world's leading manufacturers of insulating materials. It was important to use a suitable adhesive that did not impregnate the pressboard, but was resistant to transformer oil and allowed the samples to be glued to the pipe. For this purpose, experimental tests were carried out to glue the pressboard to the polycarbonate pipe with contact, polymer, acrylic and epoxy adhesives. The epoxy adhesive proved to be the most suitable both in terms of density, adhesion to the glued surfaces and oil resistance.

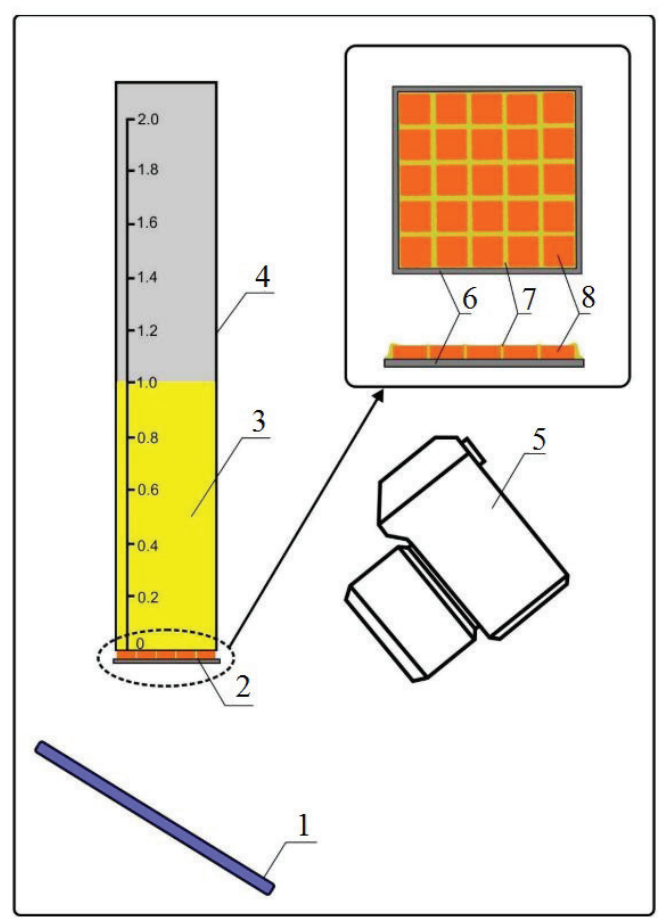

Figure 2-Outline of the measuring stand: 1 -mirror; 2 -sample matrix; 3 -insulation oil; 4-polycarbonate pipe; 5 - camera; 6 - perforated iron sheet; 7 -adhesive layer; 8 - pressboard sample
A high resolution digital camera was used to record the image. To control the operation of the camera, an intervalometer was used, allowing for cyclic release of the camera shutter in the time range of $1 \mathrm{~s}$ to $99 \mathrm{~min}$. The camera is capable of a reduction of wobble during the shooting process thanks to image stabilisation and the possibility of initial mirror lift. After a series of tests, the optimum time between shooting was determined to be $15 \mathrm{~s}$, ensuring an accuracy of approximately $0.5 \%$.

The exposure time was adjusted to the ISO200 sensitivity so that the images had the lowest noise level. The lens aperture was selected on the basis of MTF50 [lpmm] charts for maximum focal length resolution of the camera lens. White LEDs were used as the illumination of the tested sample, placed in such a way as to make the surface of the tested sample evenly illuminated. The use of a digital camera in comparison with visual observation gives the possibility to take measurements without the participation of the observer and allows for reanalysis of the set of images in order to verify the correctness of the setting of oil permeation times.

Initially, the measuring station consisted of a pipe with an internal diameter of $40 \mathrm{~mm}$ and a length of $1.5 \mathrm{~m}$, to which a $50 \times 50 \mathrm{~mm}^{2}$ pressboard plate was glued. The measurement of percolation time consisted in the analysis of obtained photographs and determination of colour changes on the surface of the tested sample. Then, knowing the number of photos taken until the first dark point appeared on the lower surface of the sample and the length of the time interval, the impregnation time of the oil through the pressboard sample was determined. Images of the sample obtained after successively increasing times are shown in Figure 3. Figure 3 shows that on the initially bright lower surface of the pressboard plate (Figure $3 a$ ) a dark point appears after some time (Figure $3 b$ ). The time after which this point appears is the time of the fastest penetration. This probably corresponds to the capillary of the largest diameter. Then the dark area around this point gradually expands (Figure $3 c$ ). This indicates that there are capillaries with longer penetration times, i. e. with smaller diameters than the first capillary. The analysis of the images presented in Figure 3 shows the presence of capillaries of significantly different diameters in the structure of the electrotechnical pressboard. 


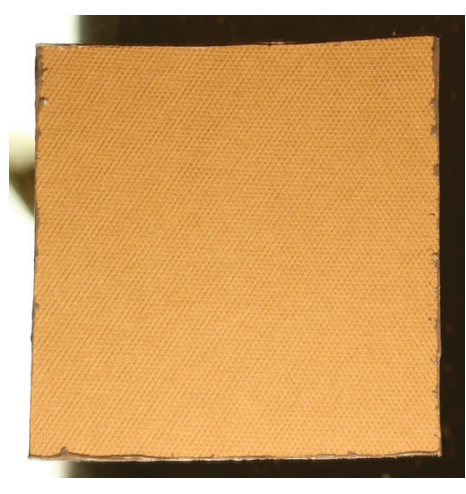

$a$

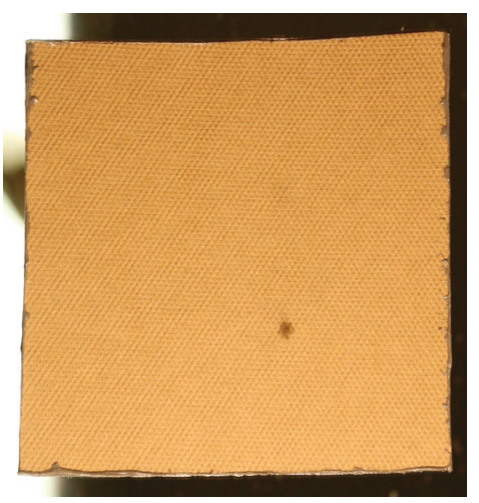

$b$

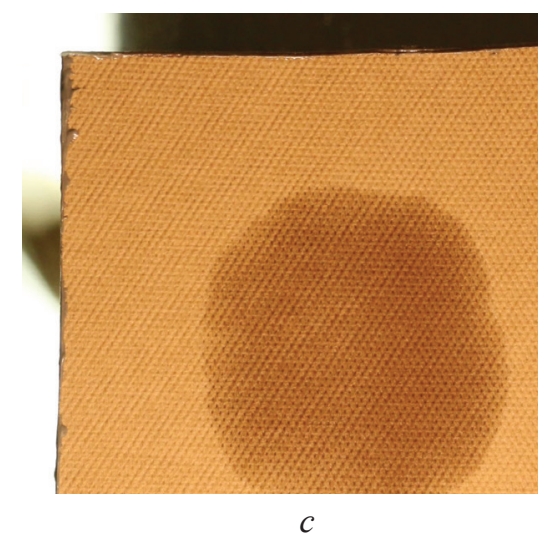

Figure 3-Images of the pressboard sample during permeation time measurements

This means that the oil permeation times differ at different points in the pressboard sample. By analysing the subsequent images it is possible to determine the moment of oil permeation at a given point. Unfortunately, in a number of cases the time differences were small, so that the surface of the sample quickly became completely dark, making it impossible to determine the individual times. By analysing a single sample, one or rarely two permeation times could be determined. In order to determine the statistical distribution of permeation times at least several dozen times had to be determined.
For this purpose, the size of the seepage area of a single sample was limited to $15 \times 15 \mathrm{~mm}$ in order to make a matrix from such samples as shown in Figure 4. The samples were glued to a perforated galvanised sheet with $10 \times 10 \mathrm{~mm}$ holes. The next step was to apply the adhesive to the cutting edges of the samples in order to eliminate the penetration of oil through the side edges of the sample. The matrix consisted of 25 samples, but after taking into account the dimensions of the $90 \mathrm{~mm}$ diameter polycarbonate pipe used in this case and the adhesive area, only 9 centrally located samples were analysed.

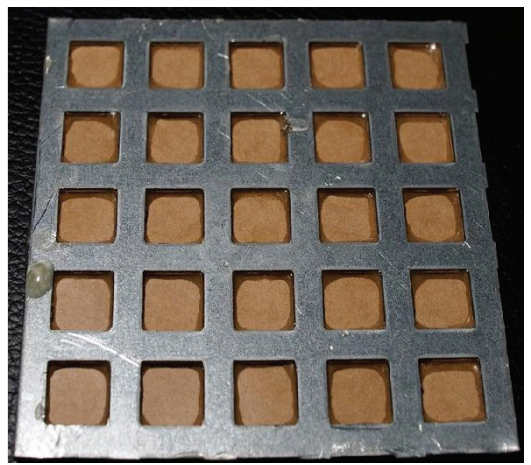

$a$

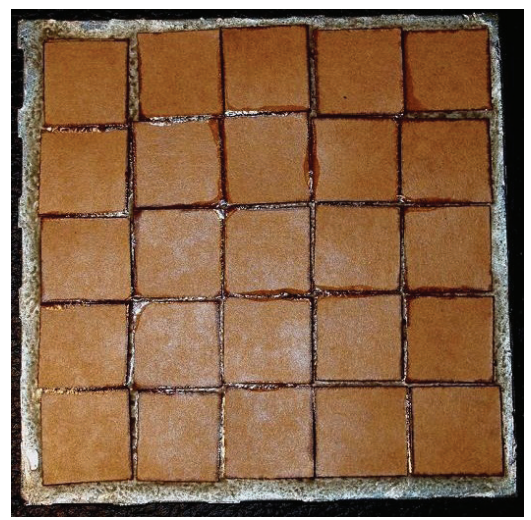

$b$

Figure 4-View of the matrix with prepared samples of presssboard: 1 -matrix view from the bottom side; 2 - from the oil side

In this way 20 matrices were made for $2 \mathrm{~mm}$ thick samples, on the basis of which 180 values of the penetration times were obtained. The distribution of the obtained permeation times is shown in Figure 5, containing the histogram of time intervals, which differ in values with a step of $30 \mathrm{~min}$. As can be seen from this figure, there are more than twofold differences in permeation times, the smallest one about $220 \mathrm{~min}$, the largest about $550 \mathrm{~min}$. 


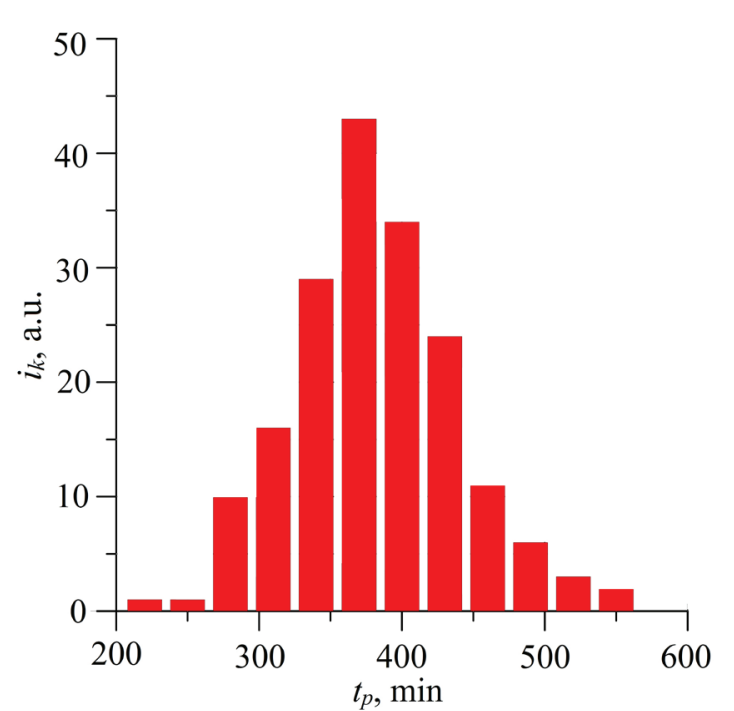

Figure 5-Histogram of the number of occurrences of individual permeation times

Penetration of oil through the pressboard is done by capillaries between the cellulose fibres. The distribution of penetration times shown in Figure 5 means that the capillaries in the pressboard are different in their rays. To determine the values of capillary rays, the Hagen-Poiseuille's law was applied:

$$
\frac{d V}{d t}=\frac{\pi r^{2} \Delta p}{8 \eta L}
$$

where $d V$-volume of oil flowing through the capillary in time $d t ; \Delta p$ - pressure inducing liquid flow in the capillary; $\eta-$ dynamic oil viscosity; $L$ - length of the capillary; $r$-radius of the capillary.

Assuming that the oil flow in the capillaries is caused by the pressure of the oil column, we obtain:

$$
\Delta p=\rho g h,
$$

where $\rho$-oil density; $g$-standard gravity; $h$-oil column height.

By substituting formula (2) with formula (1) and integrating, we obtain the expression for the volume of liquid flowing through a single capillary:

$$
V=\frac{\pi r^{4} \rho g h}{8 \eta L} t \text {. }
$$

In the study of the phenomenon of capillarity by traditional methods, formula (3) is used to determine the dynamic viscosity of a liquid, in the case of known radius and length of the capillary. When the radius of the capillary is not known, its value can be determined by observing the flow of a liquid of known viscosity. In both cases, the volume of liquid $V$, which for time $t$ will flow out through the capillary, is determined. In our case, an unknown number of capillaries of different unknown radii pass through the sample of the pressboard. Therefore, it is not possible to use the standard interpretation of formula (3) consisting in measuring the volume of oil leaking from the capillary at time $t$. In order to solve this problem, an approach has been taken to determine the time $t_{p}$ after which the oil fills the entire capillary, i.e. from the moment the pipe is filled with oil to the moment the oil permeates the sample. Such a moment is recorded when a dark point appears on one of the subsequent pictures shown in Figure 3. At $t_{p}$, the volume of oil in the capillary will be:

$V=\pi \cdot r^{2} \cdot L$,

where $r$ - radius of the capillary; $L$ - thickness of the pressboard.

By substituting the permeation time $t_{p}$ and formula (4) to formula (3) we obtain:

$$
\pi \cdot r^{2} \cdot L=\frac{\pi r^{4} \rho g h}{8 \eta L} t_{p} .
$$

From here:

$$
r=L \sqrt{\frac{8 \cdot \eta \cdot L}{\rho \cdot g \cdot h \cdot t_{p}}} .
$$

By substituting to formula (6) physical constants and the permeation times obtained from measurements, as shown in Figure 5, the distribution of capillary radius values was calculated, as shown in Figure 6. From Figure 6 it follows that the capillary radii are in the range from about 45 to about $70 \mathrm{~nm}$. According to the data presented by the employees of Weidmann, one of the leading manufacturers of cellulose products intended for the construction of insulation of electrical transformers, the dimensions of capillaries in the pressboard range from $10 \mathrm{~nm}$ to several micrometers [11]. Formula (6) shows that the radius of the capillary, calculated on the basis of the measured permeation time $t_{p}$ depends linearly on the capillary length. When calculating the radii of capillaries, the values of which are shown in Figure 6, it was assumed that the length of each capillary is equal to the thickness of the pressboard. This means that the capillary is in the form of a cylinder connecting two surfaces of the pressboard plate. The real shape of the capillary may look like a broken line. It can increase the length of the capillary by several 
times. However, taking into account that the shortest seepage times were used to calculate the radii of the capillaries, it should be assumed that the seepage was made by capillaries of lengths similar to the thickness of the pressboard. Besides, in such heterogeneous materials as cellulose fibre clusters, the capillary is unlikely to be cylinder-shaped with a constant radius. It should be assumed that the capillary consists rather of short sections of variable thickness close to the length of the cellulose fibres. This means that the achieved capillary radii are average values. Real short sections of the capillary may have radii both shorter than $45 \mathrm{~nm}$ and longer than $70 \mathrm{~nm}$. Paper [11] argues that the upper limit of capillary diameter is several $\mu \mathrm{m}$. If in the plates tested in the study there were capillaries of such diameter connecting both surfaces of the pressboard plate, according to formula (6) the time of oil permeation would be very short and would be about $20 \mathrm{~s}$. The permeation times we observed, as shown in Figure 5, are about two orders larger. This means that such large diameters concern rather short and rare sections of the capillary.

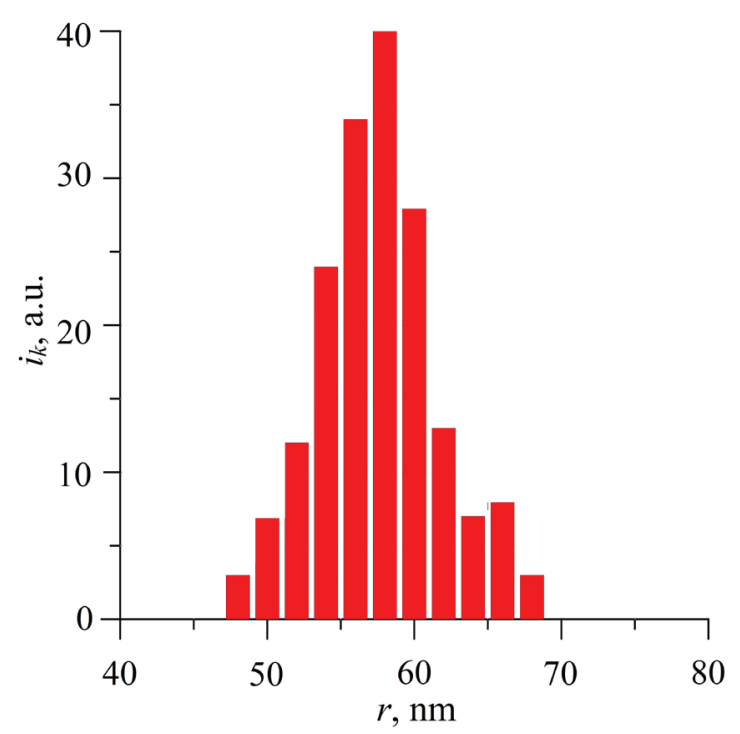

Figure 6 - The graph of the number of occurrences of particular radii of capillaries

The structure of the pressboard consists of cellulose fibres, arranged more or less tightly, between which are capillaries with radii of up to several hundred nanometres. The research shows that there are capillaries in the pressboard structure, each of which has sections of varying lengths of radii. Average values of capillary radii range from 130 to $200 \mathrm{~nm}$. Impregnation of the pressboard causes that the capillaries are filled with insulating oil. This means that the paper-oil insulation of power transformers should be considered as a composite of cellulose and nano-capillaries filled with insulating oil.

\section{Conclusion}

The paper presents a developed and constructed stand for testing the rate of penetration of transformer oil through the electrotechnical pressboard, which consists of a pipe, to the lower end of which a pressboard plate is glued. A mirror is placed under the tube at a $45^{\circ}$ angle, which directs the image of the pressboard plate to the camera lens. After flooding the tube with transformer oil, the camera takes a series of photos with a given time interval. The principle of the station is that after moistening its surface with insulating oil, the pressboard changes its colour from light to dark yellow. The soaking time is defined as the time in which, after filling the pipe with oil, a dark yellow spot appears on the lower light surface of the pressboard, recorded in subsequent pictures. On the basis of the HagenPoiseuille law describing capillary phenomena, a new way of determining capillary diameters has been developed, where the number of capillaries is unknown and the volume of liquid flowing through them is impossible to measure. On the basis of the tests carried out with the use of the stand, the penetration times of transformer oil through the $2 \mathrm{~mm}$ thick electrotechnical pressboard were determined, the values of which range from about $220 \mathrm{~min}$ to about $550 \mathrm{~min}$. The capillary radii through which the insulating oil seeps were determined to be between approx. $45 \mathrm{~nm}$ and approx. $70 \mathrm{~nm}$. Due to the structure of the pressboard, which consists of cellulose fibers, there are capillaries in the it, each of which has sections of varying lengths of radii. This means that the obtained capillary radii are average values. Real short sections of the capillary can have radii both smaller than $45 \mathrm{~nm}$ and larger than $70 \mathrm{~nm}$.

The test stand for examining the rate of penetration of liquids through porous materials and the new method of analysis of test results described in the article can be successfully used for testing other porous materials and other liquids. The condition for using the test stand and the new method of analysis of results for other materials and liquids is a change in colour or reflectance of the solid material under the influence of the liquid. These phenomena are often encountered in practice. In the absence of such features, the liquid can be coloured. 


\section{References}

1. Krause C. Power transformer insulation - history, technology and design. IEEE Trans. Dielectr. Electr. Insul., 2012, vol. 19, no. 6, pp. 1941-1947.

DOI: 10.1109/TDEI.2012.6396951

2. Jalbert J., Rodriguez-Celis E., Duchesne S., Morin B., Ryadi M., Gilbert R. Kinetics of the production of chain-end groups and methanol from the depolymerization of cellulose during the ageing of paper/oil systems. Part 3: extension of the study under temperature conditions over $120^{\circ} \mathrm{C}$. Cellulose, 2015, vol. 22, no. 1, pp. 829-848.

DOI: $10.1007 / \mathrm{s} 10570-014-0516-8$

3. Fofana I. 50 years in the development of insulating liquids. IEEE Electr. Insul. Mag., 2013, vol. 29, no. 5, pp. 13-25. DOI: 10.1109/MEI.2013.6585853

4. Huang M., Zhou Y., Zhou Z., Qi B. A Combined Electro-Thermal Breakdown Model for Oil-Impregnated Paper. Energies, 2017, vol. 10, no. 12, p. 2160.

DOI: $10.3390 / \mathrm{en} 10122160$

5. CIGRE A2.35. Experiences in service with new insulating liquids CIGRE Working Group A2.35, 2010, no. 436, pp. 1-95. DOI: ISBN:978-2-85873-124-4

6. Rogalski P., Opielak M. The effect of reduced pressure on the bubble effect in the composite celluloseinsulation oil-water nanodrops. In Proceedings Advanced Topics in Optoelectronics, Microelectronics, and Nanotechnologies IX, 2019, vol. 10977, 130 p.

DOI: $10.1117 / 12.2324860$
7. Rogalski P. Optical registration of transformer oil absorption processes in electrical pressboard nanocapillaries. In Proc. Spie 10010, Advanced Topics in Optoelectronics, Microelectronics, and Nanotechnologies VIII, 2016, vol. 10010, pp. 100101R-1-100101R-8.

DOI: $10.1117 / 12.2243269$

8. Rogalski P., Okal P. Optical registration of the vacuum impregnation process of electrotechnical pressboard by transformer oil. In Proc. Spie 10445, Photonics Applications in Astronomy, Communications, Industry, and High Energy Physics Experiments, 2017, vol. 10445, pp. 104455E-1-104455E-7.

DOI: $10.1117 / 12.2281033$

9. Rogalski P., Kozak C., Lebedynskyi I. Statistical analysis of transformer oil penetration speed through electrotechnical pressboard. In Proc. IEEE 7th International Conference Nanomaterials: Application \& Properties (NAP), 2017, pp. 02MAN11-1-02MAN11-4. DOI: $10.1109 / \mathrm{NAP} .2017 .8190356$

10. Rogalski P., Zukowski P., Korenciak D. Determination of nanocapillaries radii statistical distribution in electrotechnical pressboard. In Proceedings of SPIE - The International Society for Optical Engineering, 2018, vol. 10808.

DOI: $10.1117 / 12.2501462$

11. Moser H.P., Dahinden V., Brechna H. Transformerboard II: properties and application of Transformerboard of different fibres. Zürich: Weidmann AG, 1987. 